\title{
Depletion of suspended particulate matter over coastal reef communities dominated by zooxanthellate soft corals
}

\author{
Katharina E. Fabricius*, Michaela Dommisse \\ Australian Institute of Marine Science and CRC Reef Research, PMB 3, Townsville, Queensland 4810, Australia
}

\begin{abstract}
Coastal reef communities dominated by zooxanthellate alcyonacean octocorals extract large quantities of suspended particulate matter (SPM) from the water column. Concentrations of SPM in water parcels, tracked by a curtain drogue, were measured before and after passing over 2 strips of soft coral dominated, near-shore reefs $\sim 200 \mathrm{~m}$ long, and over 2 adjacent sand-dominated strips for comparison. The reefs were covered with $50 \%$ zooxanthellate octocorals (total. standing stock: $-270 \mathrm{~g}$ AFDW m $\mathrm{m}^{-2}$; mean live tissue volume: $70 . \mathrm{m}^{-2}$ ), $7 \%$ hard corals, $15 \%$ turf algae with bioeroding sponges underneath, and $<1 \%$ other filter feeders (sponges, tunicates, and bivalves). Downstream of the reef communities, chlorophyll, particulate organic carbon and particulate phosphorus were significantly depleted. The depletion of chlorophyll averaged $35 \%$ of the standing stock, whereas the net depletion of particulate organic carbon and particulate phosphorus was 15 and $23 \%$, respectively. Rates of depletion were similar for the 2 reef sites and 3 sampling periods, and were independent of upstream particle concentration. In contrast. concentrations of particulate nitrogen and phaeopigments were similar before and after passage across the reef sites. On the sandy sites, downstream concentrations of particulate nutrients, chlorophyll and phaeopigments were all similar to upstream concentrations. The net import of particulate organic carbon into the reef was estimated as $2.5 \pm 1.1 \mathrm{~g} \mathrm{C} \mathrm{m}^{-2} \mathrm{~d}^{-1}$. Less than $20 \%$ of this carbon import could be explained by area-specific rates of removal by sponges, tunicates, bivalves, and hard corals, suggesting that soft corals were the primary sink of carbon. The data suggest that detritus and other small SPM $(<10 \mu \mathrm{m}$ particle size $)$ are an important food source for alcyoniiddominated reef communities in high turbidity regimes.
\end{abstract}

KEY WORDS: Suspended particulate matter (SPM) - Particulate organic matter (POM) - In situ depletion $\cdot$ Budget $\cdot$ Suspension feeding A Alcyonacea - Octocorallia $\cdot$ Coral reef

\section{INTRODUCTION}

Concentrations and availability of suspended particulate matter (SPM) are known to control rates of food intake, growth and reproduction in a range of filter feeders (e.g., Barker Jørgensen 1996, Riisgård et al. 1996). Coastal coral reefs on wide shallow continental shelves are often exposed to high concentrations of SPM, due to resuspension from the sea floor and import from terrestrial run-off. River run-off is the largest source of nutrients on the Northeast Australian continental shelf, contributing to high turbidity and

\footnotetext{
•E-mail:k.fabricius@aims.gov.au
}

nutrient levels on coastal coral reefs (Furnas et al. 1997). Some coastal turbid coral reefs have become dominated by dense stands of space-monopolizing alcyoniid soft corals since the 1950s, i.e., after the clearing of coastal areas began (reviewed in Fabricius 1998). Links between increased coastal run-off (Walker \& O'Donnell 1981) and the replacement of reef-building hard corals by these soft coral assemblages have been suggested (Bell \& Elmetri 1995); however, they have so far remained unsubstantiated due to insufficient information on the diet and rates of feeding of zooxanthellate soft corals.

In this study, we investigated the rates of in situ net depletion of natural SPM (containing living and nonliving suspended particles) by reef communities domi- 


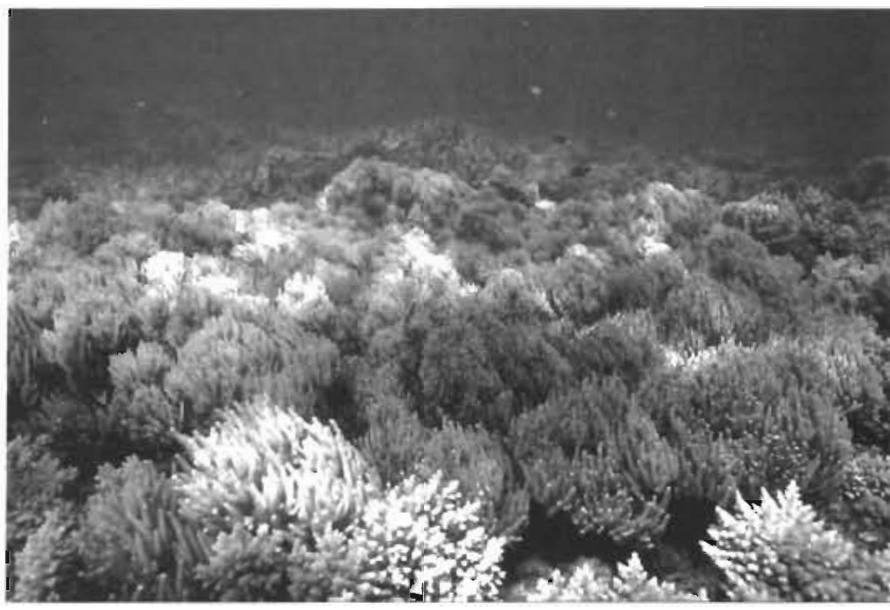

Fig. 1. Soft coral dominated reef community in Pelorus Channel, North Orpheus Island

nated by zooxanthellate alcyoniid soft corals. We estimated the net removal of chlorophyll (as a marker for phytoplankton), particulate organic carbon (POC) (for determining energy gain), and particulate nitrogen (PN) and particulate phosphorus (PP). We also determined the abundances of all groups of macro-benthos at the study sites. We focussed our investigation on a very simple reef system, in an area monopolised by alcyoniid soft corals, surrounded by extensive areas of sand with little substratum suitable for boring sponges and litophages, and with unidirectional currents (Figs. 1 \& 2). As rates of natural feeding in Alcyoniidae are unknown, we used an indirect way to estimate their contribution to the SMP removal. We calculated the potential area-specific rates of SPM removal by sponges, bivalves and tunicates based on published filtration rates. We argue that much of the removal which could not be attributed to these filter feeders is likely to be due to suspension feeding by the large standing stock of Alcyoniidae

\section{METHODS}

Study sites. The study was carried out in the Great Palm Islands group, central Great Barrier Reef, Northeast Australia (Fig. 2a). The continental islands are located 25 to $28 \mathrm{~km}$ off the coast in $<30 \mathrm{~m}$ water, and are surrounded by a sediment covered sea floor with small regions of hard substratum and few coral outcrops. Fringing reefs surround most of the islands and extend to $\sim 15 \mathrm{~m}$ depth. Resuspension of sediment from the shallow bottom, and coastal run-off during monsoonal rains contribute to a highiy variable water turbidity, with a mean $<5 \mathrm{mg}$ SPM dry weight $1^{-1}$ in areas close by (Larcombe et al. 1995). Measurements were carried out in 2 channels between adjacent islands (Pelorus Channel: latitude $18.58^{\circ} \mathrm{S}$, longitude $146.50^{\circ} \mathrm{E}$; Fantome Channel: $18.67^{\circ} \mathrm{S}$, $146.51^{\circ} \mathrm{E}$ ). On the southern shores of Pelorus and Fantome channels, the reefs are 50 to $150 \mathrm{~m}$ wide, while on the northern shores their width is $<50 \mathrm{~m}$ (Figs. 2b,c). The centers of the channels are covered with sand and interspersed sparse hard coral and soft coral stands; however a $30 \mathrm{~m}$ wide bar of coral reef crossed from one shore to the other in Fantome Channel. Sampling was done over the southern reefs, and over the sand bottom more towards the middle of the channels for comparison.

Water mixing between the reef and sand sites was probably low, as the channels represent natural large-scale flumes exposed to predominantly linear flow, accelerated by a funnel effect. Deployment of Interocean S4 current meters $0.5 \mathrm{~m}$ above the southern reef slopes at $6 \mathrm{~m}$ depth in each channel (averaging 120 readings for every 10 th minute over 3 to 4 winter days) indicated that current directions and speeds in Fantome Channel and Pelorus Channel were tidal driven. Flow was unidirectional for extended periods, with velocities of 4 to $35 \mathrm{~cm} \mathrm{~s}^{-1}$. Relative flow speeds along a $-50 \mathrm{~m}$ long transect from the reef to the sandy site were assessed in both channels with eroding hemispherical plaster blocks (calibration in Fabricius \& De'ath 1997). Two blocks were deployed at the base of each current meter, and 10 blocks were deployed in a line perpendicular to the flow, where they were left to erode for $24 \mathrm{~h}$, i.e., 2 tidal cycles. In Pelorus Channel, the mean flow recorded by the electromagnetic current meter was $12 \mathrm{~cm} \mathrm{~s}^{-1}( \pm 6 \mathrm{SD})$. The plaster blocks indicated that flow varied between 11 and $17 \mathrm{~cm} \mathrm{~s}^{-1}$, independent of distance to the shore. In Fantome Channel, mean flow at the electromagnetic current meter (positioned at $\sim 30 \mathrm{~m}$ distance from the shore) was $11 \mathrm{~cm} \mathrm{~s}^{-1}( \pm 9 \mathrm{SD})$. The plaster blocks indicated that the flow increased from $11 \mathrm{cms}{ }^{1}$ around the current meter to $23 \mathrm{~cm} \mathrm{~s}^{-1}$ towards the comparison site. Conditions during the time of flow measurements approximated normal winter conditions (wind speed: 25 to $35 \mathrm{~km} \mathrm{~h}^{-1}$, seas: $-1 \mathrm{~m}$ at the seaward sides of the channels, and tidal amplitude: 1.0 to $2.9 \mathrm{~m}$ ). Due to the complexity and variability of the current patterns, and insufficient resources for long-term deployments of current meters, we assumed that currents averaged $\sim 15 \mathrm{~cm} \mathrm{~s}^{-1}$ in both channeis for calculating nutrient fluxes and rates of SPM depletion (see below).

Water sampling. A curtain drogue $(4 \times 2.5 \mathrm{~m})$ was used to mark and follow water parcels travelling either over a $\sim 200 \mathrm{~m}$ long section of the southern fringing reef, or in the sandy center of the channels for compar- 

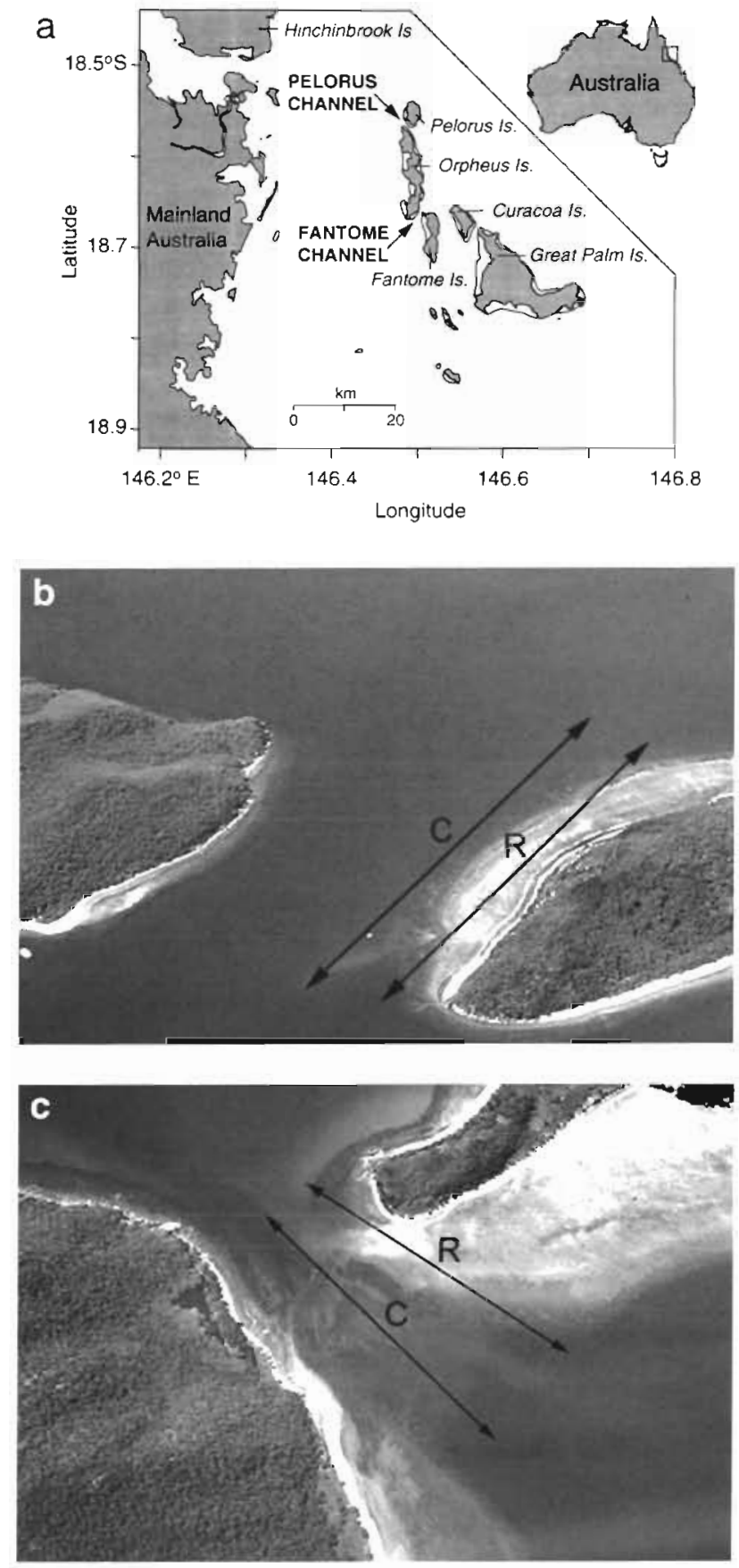

Fig. 2. The 2 study sites: Pelorus and Fantome Island Channels. (a) Location in the Great Palms Islands Group (centraI Great Barrier Reef, North Queensland). Grey shading demarcates continental land masses, contours outline fringing coral reef formations. (b) Areal photographs of Pelorus and (c) Fantome Channels. Arrows indicate the approximate length (ca $200 \mathrm{~m}$ ) and direction of the drift drogue trajectories over reef $(R)$ and comparison $(C)$ sites

ison. Three 51 Niskin bottles of water were collected on the upstream side of the reef by a snorkeller from $1.5 \mathrm{~m}$ above the bottom (at 5 to $8 \mathrm{~m}$ depth). The sam- ples were combined in an acid-washed bucket and stored in the shade. The drift drogue was released, the position (GPS) and time noted, and the drogue was followed over $\sim 350 \mathrm{~m}$ ( $\sim 200 \mathrm{~m}$ of which were over reef, with sandy sea floor before and after it). Sampling was then repeated on the downstream side of the reef. The same procedure was followed at the sandy sites, but here, the water samples were from 7 to $10 \mathrm{~m}$ depth. Samples were only collected if the drogue travelled in a straight line over the reef or sand. For safety reasons, all sampling was done during daylight (08:00 to $17: 00 \mathrm{~h}$ ).

Sampling was repeated 62 times, in 4 sets of 5 to $6 \mathrm{~d}$ in August, September and November 1996, and July 1997. In August, 7 sample sets were taken over the reefs, and 1 as control over the sand. From September on, each sample pair over the reefs was compared to a pair of samples collected over the sand. High, patchy concentrations of the pelagic nitrogen-fixing cyanobacterium Trichodesmium affected September and November 1996 samples. In September, the water was not pre-filtered and standard deviations between duplicate chlorophyll samples were high $156 \%$ of the means vs $<10 \%$ of the means in winter). As this variation was far greater than at other times, the September samples were not used. In November, the water was pre-filtered through a $10 \mu \mathrm{m}$ stainless steel mesh to remove Trichodesmium colonies, and standard deviations between duplicates were reduced to $11 \%$. The data from this sampling period therefore reflect the $<10 \mu \mathrm{m}$ particle size range only.

Laboratory analysis. Within an hour of sample collection, the buckets were brought back to the research vessel. Subsamples (250 to $400 \mathrm{ml}$ for particulate nutrients, and 100 to $400 \mathrm{ml}$ for chlorophyll and phaeopigments) of well-stirred water from the buckets were immediately filtered onto pre-combusted $1450^{\circ} \mathrm{C}$ for 8 h) 25 mm Whatman GF/F filters under low vacuum (15 to $30 \mathrm{kPa}$ ). Filters were then folded, stored in precombusted envelopes of aluminium foil, and frozen at $-18^{\circ} \mathrm{C}$ until further analysis.

After the field trip, 6 of the 8 subsamples were freezedried. Duplicate samples were analysed for POC with a Shimadzu TOC 5000 carbon analyser using ethylenediaminetetra-acetic acid (EDTA) as a standard. PN and PP were determined on duplicate samples following Furnas et al. (1995). Values obtained from blanks (precombusted filters) were subtracted from sample values. The remaining 2 subsamples were transferred from frozen state into $90 \%(\mathrm{v} / \mathrm{v})$ acetone, ground in acetone, and chlorophyll a (chl a) and phaeophytin (Phae) were determined fluorometrically (Parsons et al. 1985). In July 1997, additional $100 \mathrm{ml}$ aliquots were filtered onto 2 and $10 \mu \mathrm{m}$ Nucleopore $(25 \mathrm{~mm}$ ) filters, respectively ( 3 to 4 samples in each treatment), to assess the contribu- 
tion of pico- $(<2 \mu \mathrm{m})$ and nanoplankton $(2$ to $10 \mu \mathrm{m})$ to total community chl a.

Assessment of the benthos composition. Percent cover and abundances of individual taxa were assessed with $4 \times 50 \mathrm{~m}$ line intercept transects on the reef sites of Fantome and Pelorus Channels, recording the length of each benthos category that fell below the tape (Marsh et al. 1984). No transects were analysed at the sand-dominated comparison sites, because $50 \mathrm{~m}$ transects were too short to adequately represent individual taxa in the sparse coral community, and the brief periods of slack current did not permit longer transects. Rapid ecological assessments (Done 1982, Dinesen 1983, Devantier et al. 1998) were used for comparison of macrobenthos composition and physical parameters on reef and sand sites. During 48 swims of 10 to 15 min each 25 over the reef, and 23 over the sand sites), percent total cover of alcyoniid and other soft corals, hard corals, turf and macro algae, sand and unconsolidated rubble were estimated by 1 diver (K.E.F.) ('Tier I' in Devantier et al. 1998). Additionally, inventories of genera of soft corals and gorgonians, as well as sponges, tunicates and zoanthids (growth forms and phyla) were compiled, and abundances estimated on a ranked (ordinal) scale of 0 to 5 ('Tier II' in Devantier et al. 1998, adapted from Braun-Blanquet 1964) : 0 = absent, $1=1$ or few colonies, $2=$ uncommon, $3=$ moderately common, $4=$ common, and $5=$ dominant.

The standing crop of soft corals on the reefs was assessed by measuring the projected areas (based on longest diameter and its perpendicular diameter), and colony volumes (calculated as ellipsoids based on projected area and height) of individual colonies in each of the 6 most common soft coral genera. In order to esti- mate the biomass per $\mathrm{m}^{2}$ of soft corals, 15 colonies each of the dominant taxa Sinularia flexibilis and Sinularia capitalis (which together represented $73 \%$ of the total soft coral cover and $37 \%$ of total reef area) were collected after measuring their projected areas and height. The samples were dried to constant weight $\left(45^{\circ} \mathrm{C}\right.$ for $\left.2 \mathrm{wk}\right)$, ashed $\left(200^{\circ} \mathrm{C}\right.$ for $4 \mathrm{~h}$, followed by $450^{\circ} \mathrm{C}$ for $6 \mathrm{~h}$ ), and the ash-free dry weight (AFDW) was determined. The relationship between AFDW and colony area was linear in both taxa for the size ranges investigated (regression analysis on $S$. capitalis: AFDW $=1.003 \times$ area $-44.24, \mathrm{r}^{2}=0.646, \mathrm{p}<0.001 ;$ S. flexibilis: AFDW $=0.79 \times$ area $\left.-37.5, r^{2}=0.602, p=0.003\right)$.

Statistical analyses. Three-way fixed factor analyses of variance were used to test for effects of date $(3 \mathrm{sam}$ pling periods), channel (Pelorus and Fantome Channels), reef-sand (concentrations over the reefs versus those over the sand), and interactions between these factors, on the concentration of the 5 SPM variables (chl a, Phae, POC, PN, PP). For all analyses, non-significant terms $(p>0.05)$ were dropped from the model by backward elimination, and their sums of squares pooled with the error sum of squares (McCullagh \& Nelder 1989). Sample duplicates were averaged before analysis, q-q plots were investigated for variance homogeneity, and means were log-transformed, resulting in satisfyingly homogenous variances. Residual plots were used to check the model assumptions. Logtransformed means and 95\% confidence intervals were back-transformed for ease of interpretation.

Preliminary examination of the data suggested that changes in the downstream concentration of the 5 SPM variables were proportional to their upstream concentrations. This was confirmed by a linear regression analysis of downstream values on upstream concentra-

Table 1. Concentrations (in $\mu \mathrm{g} \mathrm{l}^{-1}$ ) of phytoplankton pigments and suspended particulate nutrients in open water ('Open': reefs upstream, and sand comparison sites upstream), and reef-downstream sites (RD) around the Great Palms Islands before passage through the channels. $\mathrm{n}=$ number of runs. $\mathrm{Chl} a=$ chlorophyll $a$, Phae = phaeopigments, POC= particulate organic carbon, $\mathrm{PN}$ and $\mathrm{PP}=$ particulate nitrogen and phosphorus, respectively. Values are back-transformed means, in brackets upper and lower $95 \%$ CI. November 1996 data include $<10 \mu \mathrm{m}$ particles only. Fixed-factor ANOVAs tested for the effects of sampling periods (August 1996. November 1996, July 1997) on concentrations of SPM in open water before channel passage. ${ }^{\cdot E r r o r} \mathrm{df}=44$

\begin{tabular}{|c|c|c|c|c|c|c|}
\hline & & $\begin{array}{l}\text { Aug } 1996 \\
(n=8)\end{array}$ & $\begin{array}{l}\text { Nov } 1996 \\
(n=20)\end{array}$ & $\begin{array}{l}\text { Jul } 1997 \\
(\mathrm{n}=20)\end{array}$ & $F_{2,45}$ & $p$ \\
\hline Chla & $\begin{array}{l}\text { Open } \\
\text { RD }\end{array}$ & 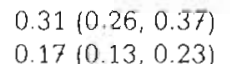 & $\begin{array}{l}0.31(0.27,0.35) \\
027(0.23,0.31)\end{array}$ & 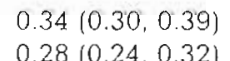 & 0832 & 0.44 \\
\hline Phae & $\begin{array}{l}\text { Open } \\
\text { RD }\end{array}$ & $\begin{array}{l}0.16(0.14,0.19) \\
0.14(0.12,0.17)\end{array}$ & $\begin{array}{l}0.22(0.19,0.25) \\
0.22(0.20,0.25)\end{array}$ & $\begin{array}{l}0.18(0.16,0.21) \\
0.19(0.17,0.21)\end{array}$ & $3.94^{\circ}$ & 0.03 \\
\hline POC & $\begin{array}{l}\text { Open } \\
\text { RD }\end{array}$ & $\begin{array}{l}162(131,200) \\
146(118,183)\end{array}$ & $\begin{array}{l}241(204,285) \\
214(186,244)\end{array}$ & $\begin{array}{l}112(1.03,122) \\
110(103,118)\end{array}$ & 32.8 & $<0.001$ \\
\hline PN & $\begin{array}{l}\text { Open } \\
\text { RD }\end{array}$ & $\begin{array}{c}11.3(10.0,12.8) \\
9.2(7.6,11.1)\end{array}$ & $\begin{array}{l}35.7(32.1,39.8) \\
34.1(31.2,37.3)\end{array}$ & $\begin{array}{l}9.88(8.8,111) \\
8.33(7.34,9.45)\end{array}$ & 157.8 & $<0.001$ \\
\hline$P P$ & Open & $\begin{array}{l}1.85(1.53,2.23) \\
1.44(1.181 .74)\end{array}$ & $\begin{array}{l}2.24(1.96,2.55) \\
2.12(1.92,2.34)\end{array}$ & $\begin{array}{l}1.88(1.74,2.04) \\
1.85(1.64,2.07)\end{array}$ & 3.03 & 0.06 \\
\hline
\end{tabular}


tions, including parameters for different slopes and intercepts for reef and sand. The best model for each of the 5 SPM variables comprised different slopes for reef and sand with each regression line passing through the origin. This suggests proportional, not constant, change in the concentration of SPM variables after their passage over the reefs; hence ratios of downstream over upstream concentrations (henceforth down/upstream ratios) were used in further analyses.

Paired t-tests were used to test for changes in relative concentrations of the different types of SPM (e.g., change in chlorophyll concentration relative to the change in carbon) during reef passage, in order to test whether some types of SPM were depleted at a greater rate than others. Log-transformed ratios of weights of carbon/chl a (and all other combinations) were compared between reef-upstream and reef-downstream samples.

Area-specific filtration rates of chlorophyll and particulate nutrients were modelled after Riisgård (1998):

$$
F=\frac{v y}{x} \ln \left(\frac{C_{\mathrm{D}}}{C_{\mathrm{U}}}\right)
$$

where $F$ is the volume of water processed by filter feeders of a given area $\left(\mathrm{m}^{3} \mathrm{~m}^{-2} \mathrm{~s}^{-1}\right), C_{D}$ and $C_{U}$ are concentrations upstream and downstream, respectively $\left(\mathrm{g} \mathrm{m}^{3}\right), v$ is flow speed $\left(\mathrm{m} \mathrm{s}^{-1}\right), y$ is the thickness of the mixed layer above the filter feeders $(m)$, and $x$ is the distance between up-and downstream sampling points (m).

The weight of material removed daily by the reef, $R$ $\left(\mathrm{g} \mathrm{m}^{-2} \mathrm{~d}^{-1}\right)$, was then calculated based on a re-arrangement and expansion of Eq. (1); thus $R=F \times\left(C_{U}+C_{D}\right) / 2$, and extrapolated from seconds to $24 \mathrm{~h}$ :

$$
R=\frac{(60 \times 60 \times 24)\left(C_{U}+C_{D}\right) V y}{2 x} \ln \left(\frac{C_{U}}{C_{D}}\right)
$$

\section{RESULTS}

\section{Temporal and spatial patterns of SPM concentrations}

In the open water (i.e., upstream, before channel passage), concentrations of all measured variables of SPM were similar over reef and sand, and between the 2 channels, at any of the sampling periods (3-way ANOVA testing for the effects of sand-reef, sampling period, channels, and interactions, on each of the nutrients: $p>0.05$ ). However, open water concentrations of phaeopigments, PN, and POC varied between the 3 sampling periods (Table 1). In particular the PN concentrations were greatly enhanced during the Trichodesmium bloom (November 1996) despite removal of $>10 \mu \mathrm{m}$ particles, compared with the 2 winter sam-

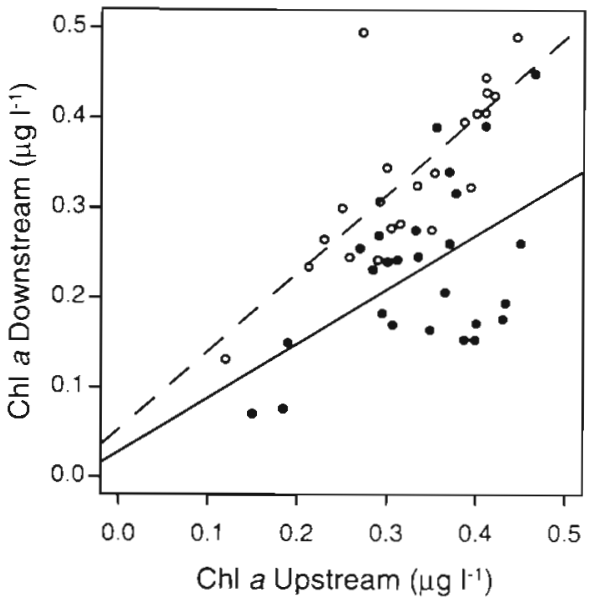

Fig. 3. Plot of downstream chlorophyll concentrations in relation to upstream chlorophyll concentrations at reef (filled circles, solid line) and comparison sites (open circles, dashed line) sites. Data are pooled from both channels and 3 sampling periods, lines represent linear regression functions

pling periods (August 1996 and July 1997) when the whole particle size spectrum was analysed.

Chl a concentrations at the downstream sites were depleted in proportion to the concentration measured upstream (regression analyses of down/upstream concentrations: Fig. 3). The regression lines for reef and sand sites both passed through the origin $\left(F_{2,44}=0.419\right.$. $\mathrm{p}=0.67)$, whereas their slopes differed significantly $\left(F_{1,46}=32.1, p<0.001\right)$. This pattern was similar in the other SPM variables (POC, PN, PP, and phaeopigments), and thus analyses of depletion were done on log-transformed ratios of down/upstream concentrations for each of the 5 SPM variables.

The ratios of down/upstream concentrations of the 5 SPM variables did not vary between channels and sampling periods, and none of the channels, date, and treatment interactions were significant (3-way ANOVAs, $p>0.051$. At the sand sites, the down/upstream ratios were not significantly different from 1 for any of the 5 SPM variables (3-way ANOVAs, p > 0.05; Fig. 4).

\section{Chlorophyll and phaeopigments}

The down/upstream ratio in chI a concentrations after reef passage was $0.65(95 \% \mathrm{CI}=[0.61,0.69])$, and after passage over the sand sites $1.00(0.98,1.02)$. The difference suggests that reef passage reduced the concentration of chl a by $35 \% \pm 7 \mathrm{SE}$ (Fig. 4, Tables 1 \& 2). The reduction in chl a due to reef passage in the $<10 \mu \mathrm{m}$ fraction in November 1996 was not different to the reduction at other times. 


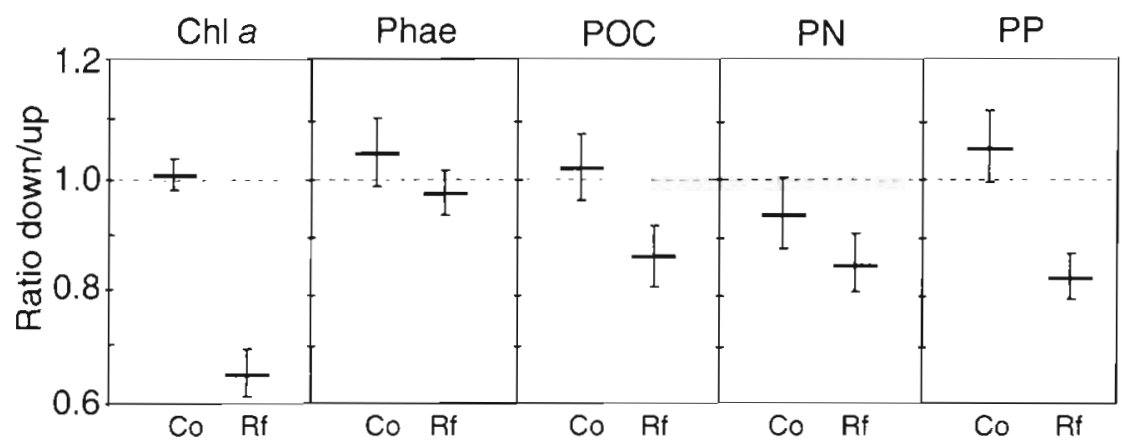

Fig. 4. Ratio of downstream/upstream concentrations in suspended particulate matter after passage over the reef (Rf) and sandy comparison (Co) sites. Values are back-transformed log (means) and $\log$ (standard errors)

Concentrations of phaeopigments, the breakdown product of chlorophyll, varied widely and did not show any discernible patterns (Fig. 4, Table 2). The down/upstream ratio in concentrations of phaeopigments was $0.98(0.94,1.01)$ over the reef and 1.04 $(0.98,1.10)$ over the sandy comparison sites, respectively. Accordingly, the ratio of chlorophyll to phaeopigments downstream of soft coral beds was lower $(1.16[1.09,1.25])$ compared to the upstream sites $(1.74[1.68,1.81])$.

As expected (Furnas \& Mitchell 1988, Ayukai 1991), small size fractions dominated the algal biomass. In July 1997, the concentration of chl $a$ in the $<2 \mu \mathrm{m}$ fraction was $68.7 \pm 2.4 \%$ of total chl $a$ at sandy and reef-upstream sites, and $58.1 \pm 7.0 \%$ at the reefdownstream sites. Similarly, the chl a in the $<10 \mu \mathrm{m}$

Table 2. Test for the difference in ratios (log[downstream/ upstream]) of concentrations of SPM between passage over the reef compared with passage over sand sites. Details of the methods are explained in 'Methods: statistical analyses'. - Error $\mathrm{d} f=45$

\begin{tabular}{|lllllc|}
\hline & Chl a & Phae & POC & PN & PP \\
\hline$F_{1,46}$ & 33.03 & $1.037^{\circ}$ & 4.737 & 1.501 & 13.26 \\
$\mathrm{p}$ & $<0.001$ & 0.314 & 0.035 & 0.227 & 0.001 \\
\hline
\end{tabular}

size fraction was $85.7 \pm 2.0 \%$ of total chl $a$ at sand and reef-upstream sites, and $58.5 \pm 6.1 \%$ downstream of reefs. Removal of chl $a$ in $<2 \mu$ algae was $48 \pm 19 \%$, while chl a from all size fractions was reduced by $35 \pm$ $7 \%$. A preferential depletion of the small size fraction was consistent over most samples, but the sample size was too small to demonstrate significance.

\section{Particulate organic carbon}

At the sand sites, the down/upstream ratios of POC averaged $1.01(0.96,1.07)$, whereas at the reef sites, the ratios averaged $0.86(0.81,0.91)$. Thus, the depletion of POC over the reef differed from that at the sand sites on average by $15.4 \pm 7.9 \%$ (Fig. 4 , Table 2 ). The reduction in POC due to reef passage in the $<10 \mu \mathrm{m}$ fraction in November 1996 was not different from the reduction of total POC at other times. The ratio of POC/chl a weight was significantly higher (683) in the reef-downstream samples than in reef-upstream waters (513) (Table 3). Assuming a carbon to chl a ratio of 30 for young, fast-growing phytoplankton (Furnas 1991, Campbell et al. 1994, Cloern et al. 1995), phytoplankton carbon in reef-upstream sites was $8.4 \pm 1.1 \%$ of the total organic carbon, whereas this proportion was significantly lower $(6.4 \pm 1.1 \%$ of carbon) downstream of the reefs (paired $t$-test, $t_{25}=3.02, \mathrm{p}=0.006$ )

Table 3. Ratios of weights of suspended particulate nutrients and chlorophyll upstream and downstream of the soft coral dominated reefs. Probabilities are based on paired $t$-tests on the log-transformed ratios of weights (reef-downstream/reef-upstream). The ratios presented here are back-transformed means land $95 \%$ Cls, representing the precision of individual ratios, not down/upstream comparisons)

\begin{tabular}{|lcccc|}
\hline & Reef-upstream & Reef-downstream & $t_{25}$ & $\mathrm{p}$ \\
\hline POC/chl $a$ & $513(416,633)$ & $683(541,846)$ & 3.02 & 0.006 \\
PN/chl $a$ & $45.6(35,5,58.6)$ & $59.4(45.4,77.7)$ & 4.25 & $<0.001$ \\
PP/chl a & $6.37(6.01,6.76)$ & $8.08(7.47,8.75)$ & 3.66 & 0.001 \\
POC/PN & $11.3(9.97,12.7)$ & $11.4(9.26,14.0)$ & 0.10 & 0.92 \\
POC/PP & $80.5(68.3,94.9)$ & $83.7(71.4,98.1)$ & 0.74 & 0.46 \\
PN/PP & $7.16(5.87,8.72)$ & $7.35(5.68,9.51)$ & 0.47 & 0.65 \\
\hline
\end{tabular}


Table 4. Percent cover of major benthos groups on reef sites at the Fantome and Pelorus Island Channels, assessed by $50 \mathrm{~m}$ line intercept transects. Data are means \pm 1 standard error of 4 transects per reef. 'Alcyoniid soft coral' is a subset of 'Total soft coral'

\begin{tabular}{|c|c|c|c|c|c|c|c|c|}
\hline & $\begin{array}{c}\text { Total } \\
\text { soft coral }\end{array}$ & $\begin{array}{l}\text { Alcyoniid } \\
\text { soft coral }\end{array}$ & $\begin{array}{l}\text { Hard } \\
\text { coral }\end{array}$ & $\begin{array}{l}\text { Turf algae' } \\
\text { macroalgae }\end{array}$ & Sponges & Zoanthids & Tunicates & $\begin{array}{l}\text { Sand/ } \\
\text { rubble }\end{array}$ \\
\hline Fantome & $43.7 \pm 10.4$ & $38.4 \pm 7.9$ & $11.6 \pm 4.4$ & $8.3 \pm 3.6$ & $1.2 \pm 0.7$ & $0.0 \pm 0.0$ & $0.01 \pm 0.01$ & $35.2 \pm 17.5$ \\
\hline Pelorus & $52.8 \pm 5.6$ & $51.4 \pm 5.6$ & $4.2 \pm 1.9$ & $18.2 \pm 5.0$ & $0.5 \pm 0.2$ & $0.4 \pm 0.2$ & $0.01 \pm 0.01$ & $24.0 \pm 8.9$ \\
\hline Mean \% & $49.7 \pm 4.9$ & $47.0 \pm 4.8$ & $6.7 \pm 2.1$ & $14.9 \pm 3.8$ & $0.7 \pm 0.2$ & $0.3 \pm 0.1$ & $0.01 \pm 0.01$ & $27.7 \pm 7.9$ \\
\hline
\end{tabular}

Table 5. Standing crop, given as expanded colony volume per square meter, of the most common soft coral genera in the reefs of Fantome and Pelorus Island Channels. Measurements were done on randomly selected colonies from 2 areas of $>500 \mathrm{~m}^{2}$ each. Values are means \pm SE. $n=$ number of colonies analyzed. na = not assessed. Percent cover is based on eight $50 \mathrm{~m}$ line intercept transects

\begin{tabular}{|lrccccccc|}
\hline Taxon & $\mathrm{n}$ & $\begin{array}{c}\text { Diameter } \\
(\mathrm{cm})\end{array}$ & $\begin{array}{c}\text { Area } \\
\left(\mathrm{cm}^{2}\right)\end{array}$ & $\begin{array}{c}\text { Height } \\
(\mathrm{cm})\end{array}$ & $\begin{array}{c}\text { Volume } \\
(1)\end{array}$ & $\begin{array}{c}\text { Cover } \\
(\%)\end{array}$ & $\begin{array}{c}\text { Soft coral } \\
\text { volume } \\
\left(1 \mathrm{~m}^{-2}\right)\end{array}$ & $\begin{array}{c}\text { Standing } \\
\left(\mathrm{g} \mathrm{AFDW} \mathrm{m} \mathrm{m}^{-2}\right)\end{array}$ \\
\hline Sinularia flexibilis & 152 & $19 \pm 1$ & $332 \pm 25$ & $19 \pm 1$ & $5.2 \pm 0.6$ & $26.0 \pm 4.0$ & $40.4 \pm 8.3$ & $122.6 \pm 29.6$ \\
Sinularia capitalis & 108 & $51 \pm 5$ & $2975 \pm 627$ & $24 \pm 1$ & $53.8 \pm 10.9$ & $11.1 \pm 3.1$ & $20.0 \pm 8.1$ & $74.7 \pm 28.1$ \\
Sinularia spp. & 45 & $33 \pm 3$ & $1345 \pm 425$ & $11 \pm 2$ & $7.3 \pm 1.6$ & $7.8 \pm 2.4$ & $4.8 \pm 2.0$ & $\mathrm{na}$ \\
Sarcophyton & 33 & $29 \pm 4$ & $1085 \pm 295$ & $14 \pm 2$ & $17.2 \pm 5.7$ & $1.3 \pm 0.5$ & $2.1 \pm 1.3$ & $\mathrm{na}$ \\
Lobophytum & 17 & $23 \pm 4$ & $553 \pm 200$ & $13 \pm 2$ & $7.6 \pm 4.0$ & $0.6 \pm 0.2$ & $0.8 \pm 0.6$ & $\mathrm{na}$ \\
Nephthea & 24 & $16 \pm 2$ & $258 \pm 58$ & $13 \pm 1$ & $3.1 \pm 0.9$ & $1.2 \pm 0.9$ & $1.4 \pm 1.2$ & $\mathrm{na}$ \\
Total & 379 & & & & & $48.1 \pm 3.8$ & $69.6 \pm 12.0$ & $197.2 \pm 40.8$ \\
\hline
\end{tabular}

\section{Particulate nitrogen}

The down/upstream ratio of PN averaged $0.85(0.80$, $0.90)$ at the reefs, and $0.93(0.86,0.99)$ at the sand sites. Thus, although concentrations of PN decreased by $15 \%$ during the reef passage, they also dropped by $7 \%$ during passage over the sand, and the difference in ratios between sand and reefs $(7.9 \pm 8.6 \%)$ was not significant (Fig. 4, Table 2). The ratio of PN/chl a increased by $\sim 23 \%$ during reef passage, while the ratio of POC/PN did not change (Table 3).

\section{Particulate phosphorus}

PP was significantly depleted by reef passage: down/ upstream ratios of PP were 23.0\% 7.3 lower over the reef than over the sand (Fig. 4, Tables $1 \& 2$ ). The reef passage increased the ratio of $\mathrm{PP} / \mathrm{chl}$ a by $21 \%$, whereas the ratios of POC/PP, and PN/PP did not change significantly (Table 3 ).

\section{Benthos communities on reef and sand sites}

The line intercept data from the reef sites indicated that the area covered by soft corals was $\sim 50 \% \pm 5 \mathrm{SE}$, whereas the cover of scleractinian (hard) corals was $7 \% \pm 2$ SE (Table 4 ). Few cryptic filter feeders (oscula of boring sponges, Lithophaga, and polychaetes) were found during careful surveys along the transect tapes, due to the sparsity of suitable substratum. Total cover of epibenthic sponges, bivalves and tunicates amounted to $<1 \%$. Thus, soft coral cover was $>50$ times that of other epibenthic macro-filter feeders. The relative abundance of (mostly large) soft coral colonies was about 18 times greater than that of the (predominantly small) epibenthic sponges and tunicates together.

Rapid ecological assessments, used to compare reef and sand sites, indicated a mean soft coral cover of $53 \%$ on the reef sites, compared to $8 \%$ on the sanddominated sites. Mean hard coral cover was estimated as $10 \%$ on the reefs and $9 \%$ on sand. Sand and unconsolidated algae-free coral rubble covered $29 \%$ on the reef, and $72 \%$ on the sandy comparison sites. The remaining area was occupied by turf and macroalgae. Alcyoniidae dominated the reef and sand communities (Fig. 1, Table 4), consisting of the genera Sinularia, Sarcophyton, Lobophytum, Cladiella, Alcyonium, and Parerythropodium (in descending order by their mean rank abundance). Dendronephthya, Isis hippuris, Melithaea, Junceella, Dichotella, Ellisella, and Plexauridae were uncommon to rare both on reef and sand sites. The xeniids Xenia, Efflatounaria, and Anthelia, 
and the nephtheids Nephthea, Scleronephthya, and Paralemnalia were uncommon to rare on the reefs, and absent on the sand sites.

On both reefs, the standing stock of soft corals, measured as expanded colony volume, was high $(70 \pm 121$ $\mathrm{m}^{-2}$ of live soft coral colony tissue; Table 5). The AFDW of Sinularia flexibulis and Sinularia capitalis (the 2 most common taxa, which together accounted for $-73 \%$ of the total soft coral cover) was $470 \pm 40 \mathrm{~g} \mathrm{AFDW} \mathrm{m}^{-2}$ colony area $(\mathrm{n}=15)$, and $670 \pm 70 \mathrm{~g} \mathrm{AFDW} \mathrm{m}^{-2}$ colony area $(n=15)$, respectively. Their mean cover was 26 and $11 \%$ (Table 5); thus, combined, the standing crop of these 2 species alone was $200 \pm 60 \mathrm{~g} \mathrm{AFDW} \mathrm{m}^{-2}$ reef area.

\section{DISCUSSION}

\section{Heterotrophy in alcyoniid-dominated near-shore reefs}

Near-shore reef communities dominated by Alcyoniidae depleted large quantities of SPM. The communities grazed with greatest efficiency on phytoplankton (chlorophyll removal of $35 \%$ ), but also made extensive use of other, non-fluorescing SPM (net removal of 8 to $23 \%$ of particulate nutrients). Traditionally, the net organic production of coral reefs is believed to be very close to zero, suggesting that nutrient export approximates its import, and that reefs are thus neither a net source nor sink of nutrients (Crossland \& Barnes 1983, see also review in Erez 1990). On the alcyoniid-dominated near-shore reefs of this study, the net balance of SPM (removal by grazing versus addition by locally produced particulate matter such as coral mucus, bacteria, or detritus) indicated that import greatly exceeded export, and that net production of the benthos was positive

The calculation of an area-specific daily net removal rate of SPM (in $\mathrm{g}$ SPM m $\mathrm{m}^{-2} \mathrm{~d}^{-1}$ ) by the $\sim 200 \mathrm{~m}$ long strip of reef was based on an estimated mean flow speed of $15 \mathrm{~cm} \mathrm{~s}^{-1}$. We also assumed a mixed-layer thickness of $1.5 \mathrm{~m}$. This assumption is probably conservative, as the water samples were taken $\sim 1.5 \mathrm{~m}$ above the substrate, and fluid mechanical argument and field observations indicate extensive mixing in the fast and turbulent flow over the reef: colonies were subjected to Reynolds number of $\operatorname{Re}=10^{5}$ to $10^{6}$ at $15 \mathrm{~cm} \mathrm{~s}^{-1}$ flow (Vogel 1981), where the boundary layer thickness is small $\left(\sim 10^{-2}\right.$ to $\left.10^{-3} \mathrm{~m}\right)$, and broken up by surface protrusions at scales of $10^{-3}$ to $>1 \mathrm{~m}$ (Thorpe 1984). Furthermore, vertical mixing takes place along sloping boundaries with high surface roughness, resulting in well-mixed conditions several meters over reefs even in relatively calm lagoons (Wolanski 1987). Yahel et al. (1998) also recorded a 1 to $3 \mathrm{~m}$ layer of phytoplankton-depleted water above reefs of the northern Red Sea; however, conditions were much calmer and thus presumably less mixed. At a flow rate of $0.15 \mathrm{~m} \mathrm{~s}^{-1}, 19440 \mathrm{~m}^{3}$ water pass through a $1.5 \mathrm{~m}$ deep layer over a $1 \mathrm{~m}$ wide strip of reef per day. The net area-specific filtration rate of phytoplankton by the reef community was $42 \mathrm{~m}^{3} \mathrm{~m}^{-2}$ $\mathrm{d}^{-1}$, and that of carbon $16 \mathrm{~m}^{3} \mathrm{~m}^{-2} \mathrm{~d}^{-1}$ (Table 6). Estimates of daily net removal rates of SPM by the soft coral dominated reef community are summarized in Table 6.

The estimate of carbon import was $2.5 \pm 1.1 \mathrm{~g} \mathrm{~m}^{-2}$ $\mathrm{d}^{-1}$, or $897 \pm 394 \mathrm{~g} \mathrm{~m}^{-2} \mathrm{yr}^{-1}$. Phytopiankton carbon contributed only $14 \%\left(125 \pm 27 \mathrm{~g} \mathrm{~m}^{-2} \mathrm{yr}^{-1}\right)$ to this carbon import. Additionally, $16 \pm 6 \mathrm{~g} \mathrm{~m}^{-2} \mathrm{yr}^{-1}$ of phosphorus, and $58 \pm 22 \mathrm{~g} \mathrm{~m}^{-2} \mathrm{yr}^{-1}$ of nitrogen were imported into the system. A carbon removal rate of $897 \mathrm{~g} \mathrm{~m}^{-2}$ $\mathrm{yr}^{-1}$ by a soft coral dominated reef in near-shore GBR waters, where turbidity is primarily due to suspended detrital matter, is similar to the phytoplankton removal rates by azooxanthellate soft corals in the northern Red Sea, where phytoplankton is the predominant source of SPM (Yahel et al. 1998). A Red Sea reef dominated by azooxanthellate soft corals including Dendronephthya removed $\sim 720 \mathrm{~g}$ phytoplank-

Table 6 . Rates of chl $a$ and nutrient filtration and removal by reefs dominated by alyconiid soft corals. The estimate of phytoplankton carbon is based on a carbon to chlorophyll conversion factor of 30 , and the assumption that a $1.5 \mathrm{~m}$ thick layer of water is depleted homogenously. Values are means $\pm \mathrm{SE}$

\begin{tabular}{|c|c|c|c|c|}
\hline & $\begin{array}{c}\text { Net depletion } \\
(\%)\end{array}$ & $\begin{array}{c}\text { Upstream } \\
\text { concentration } \\
\left(\mu \mathrm{g} \mathrm{I}^{-1}\right)\end{array}$ & $\begin{array}{l}\text { Area-specific } \\
\text { filtration rate, } F \\
\left(\mathrm{~m}^{-3} \mathrm{~m}^{-2} \mathrm{~d}^{-1}\right)\end{array}$ & $\begin{array}{l}\text { Rate of removal, } \\
\quad R\left(\mathrm{~g} \mathrm{~m}^{-2} \mathrm{~d}^{-1}\right)\end{array}$ \\
\hline Chl a & $35.0 \pm 7.1$ & $0.33 \pm 0.01$ & $42 \pm 90$ & $0.011 \pm 0.0025$ \\
\hline Phytoplankton C & $35.0 \pm 7.1$ & $9.8 \pm 1.4$ & $42 \pm 9.0$ & $0.34 \pm 0.074$ \\
\hline POC & $15.4 \pm 8.0$ & $164.1 \pm 6.2$ & $16 \pm 7.0$ & $2.5 \pm 1.054$ \\
\hline PN & $8.9 \pm 8.6$ & $14.9 \pm 1.3$ & $9.0 \pm 3.4$ & $0.045 \pm 0.017$ \\
\hline PP & $23.0 \pm 7.3$ & $1.98 \pm 0.05$ & $25 \pm 9.8$ & $0.16 \pm 0.06$ \\
\hline Phae & $6.4 \pm 6.8$ & $0.20 \pm 0.01$ & $6.5 \pm 0.9$ & $0.0012 \pm 0.0002$ \\
\hline
\end{tabular}


ton carbon $\mathrm{m}^{-2} \mathrm{yr}^{-1}$ (Yahel et al. 1998), and a monospecific thicket of $D$. hemprichi imported $414 \mathrm{~g} \mathrm{~m}^{-2}$ $\mathrm{yr}^{-1}$ (Fabricius et al. 1998). It is noteworthy that all 3 estimates of in situ depletion of particulate organic matter by soft coral dominated communities are 1 order of magnitude higher than those reported for hard coral dominated reef flats (Glynn 1973, Johannes \& Gerber 1974, Ayukai 1995).

The contributions of the various groups of filter feeders to the SPM depletion over the reef community are not known, as direct measurements on the diet and filtration rates of the diverse groups could not be obtained in the present study. It is known that the diet of sponges, tunicates and bivalves consists predominantly of the very small size fraction of particulate matter (e.g., Harbison \& McAlister 1979, Barker Jørgensen 1996, Pile 1997). Evidence increases that the diet of octocorals also consists predominantly of relatively small $(<200 \mu \mathrm{m})$ SPM, including phytoplankton, ciliates, dinoflagellates, coral mucus, and small, weakly swimming zooplankton (Lewis 1982, Lasker et al. 1983, Coffroth 1984, Sebens \& Koehl 1984, Best 1988, Fabricius et al. 1995a,b, Ribes et al. 1998). Filtration rates depend on food concentration, flow, particle sizes, and temperature, and published area-specific rates of removal of some species of sponges, tunicates, and bivalves vary by 1 or 2 orders of magnitude within phyla (reviewed in Gili \& Coma 1998). For example, tropical sponges ingest 0.080 to $1.8 \mathrm{~g} \mathrm{C} \mathrm{m}^{-2} \mathrm{~d}^{-1}$, and values of ascidians and molluscs range from 0.02 to $3.6 \mathrm{~g} \mathrm{C} \mathrm{m}^{-2} \mathrm{~d}^{-1}$. Natural rates of feeding have been assessed for a gorgonian (Ribes et al. 1998) and an azooxanthellate soft coral (Fabricius et al. 1998); however, they are still largely unknown for tropical zooxanthellate soft corals (Alcyoniinae). This is despite the fact that more than $98 \%$ of octocorals in shallow-water regions on the central Great Barrier Reef are soft corals and zooxanthellates (Fabricius 1997).

Using existing data on filtration rates of sponges, tunicates and bivalves, we attempted to get some indirect estimates of the potential contribution of the alcyoniid soft corals to the depletion over the study sites. The transect measurements indicated a $<1 \%$ surface cover by epibenthic sponges, tunicates, bivalves, and other filter feeders; however, to be conservative, we here assumed that, additionally, the entire area of dead coral covered with turf algae contained bioeroding sponges (i.e., 15\% sub-surface cover). Assuming the highest published ingestion rate for sponges $(1.8 \mathrm{~g} \mathrm{C}$ $\mathrm{m}^{-2} \mathrm{~d}^{-1}$, Gili \& Coma 1998) is applicable for the $16 \%$ cover of filter feeders, their contribution to the community filtration rate was $\left(0.16 \times 1.8 \mathrm{~g} \mathrm{C} \mathrm{m}^{-2} \mathrm{~d}^{-1}\right)=0.29 \mathrm{~g}$ $\mathrm{C} \mathrm{m}^{-2} \mathrm{~d}^{-1}$. This represented $\sim 12 \%$ of the measured net grazing rate of $2.5 \mathrm{~g} \mathrm{C} \mathrm{m}^{-2} \mathrm{~d}^{-1}$. Demersal zooplankton and the $7 \%$ hard corals would also have contributed an unknown amount to the depletion (Sorokin 1995, Anthony 1999), although all our measurements were carried out during the day, and these groups feed predominantly at night. Pelagic bacteria and zooplankton probably contributed only little to the grazing, as they would have also depleted particles in the water column over the sand sites, and our data showed no evidence of this. Therefore, it seems a conservative estimate that the combined contribution of sponges, bivalves, tunicates, hard corals, and demersal zooplankton to the observed community grazing was $<20 \%$ of total filtration rates, indicating that the $50 \%$ cover of alcyoniid soft corals may have contributed $>80 \%$ to the depletion of small particulates. Their area-specific daily rate of removal thus calculated as $\sim 4.4 \mathrm{~g}$ POC (m colony area $)^{-2} d^{-1}$. This rate is above those published for sponges; however, a 'biomass-specific' ingestion rate may be more appropriate for comparison, taking into account not only the cover but also the large size and volumes of the alcyoniids. Based on the assumptions listed above, the mean biomass-specific ingestion rate of the alcyoniid community (with a total standing stock of $-270 \mathrm{~g} \mathrm{AFDW}^{-2}$, or $70 \mathrm{l}$ tissue $\mathrm{m}^{-2}$ ) would then approximate $0.01 \mathrm{~g} \mathrm{C}(\mathrm{g} \mathrm{AFDW})^{-1} \mathrm{~d}^{-1}$, or $0.03 \mathrm{gC}$ (l live tissue $)^{-1} d^{-1}$.

\section{SPM environment}

SPM concentrations were well within the range observed in GBR waters (Furnas et al. 1995). The ratio of C:N:P of the SPM was low $(83: 7: 1)$ compared to the Redfield ratio for phytoplankton (106:16:1; Redfield et al. 1963), the PP content of the SPM being elevated compared to that of phytoplankton. Given the exposure of the study site to particle-bound phosphorus suspended in flood plumes, and the capacity of carbonate sediments to bind phosphorus (Entsch et al. 1983), the elevated phosphorus levels are not surprising. However the $\mathrm{C} / \mathrm{N}$ ratio was higher $(12.8$ reefupstream, and 9.2 reef-downstream) than expected for proteinaceous material (Furnas et al. 1995), despite potential N-fixation by Trichodesmium. For comparison, the TOC/ $\mathrm{N}$ ratio in the tissue of an alcyoniid soft coral common on the study sites, Sarcophyton cinereum, was $6.8 \pm 0.6(n=10, K . E . F$. unpubl. data).

The similarity in the ratios of $P N$ and $P P$, and POC and $P P$ between upstream and downstream water samples indicated that there was no preferential removal of $\mathrm{PP}$ over POC or PN by the reef. However chl a was removed at a greater rate than both POC and PN. Phytoplankton carbon comprised $8.4 \pm 1.1 \%$ of the total organic carbon in reef-upstream and sandy sites, and was significantly less $(6.4 \pm 1.1 \%)$ at the reefdownstream sites. This difference indicated that either 
POC was excreted by the reef (possibly as soft coral mucus or detritus), and/or that phytoplankton uptake was more efficient than the uptake of other types of POC. The data also indicate that particulate matter other than phytoplankton (probably including labile detritus, microzooplankton, and bacteria) plays an important role ( $>90 \%$ of carbon intake) in the nutrition of these communities in high turbidity regimes.

The ratio of chlorophyll to phaeopigments was lower downstream of the soft coral dominated reef communities than upstream. This is evidence for the intake and digestion of phytoplankton, since ageing (and consequent transformation from chlorophyll to phaeopigments, the degradation products of chlorophyll) during the $0.5 \mathrm{~h}$ reef passage appeared unlikely. It also indicated that little phaeopigment was excreted (e.g., as faecal pellets or pseudofaeces), because phaeopigments did not increase at the same rate as chlorophyll a decreased.

Species-poor stands of space-monopolizing alcyoniid soft corals such as the ones investigated in this study dominate some turbid coastal fringing reefs; however, they have never been recorded on clearwater reefs further off the coast (reviewed in Fabricius 1998). On near-shore reefs around the study area, mean levels of suspended particulate nutrients are up to 30 times higher than the concentrations found on outer-shelf reefs (Walker \& O'Donnell 1981, Wolanski \& van Senden 1983, Furnas et al. 1995, Furnas \& Brodie 1996, Dommisse \& Furnas 1998), and nearshore chlorophyll concentrations may be 8 times that of outer-shelf waters (Revelante \& Gilmartin 1982). This study provides first indications of trophic processes in alcyoniid-dominated communities. It suggests that SPM is utilised by Alcyoniidae, and that turbid water with high concentrations of SPM represent a suitable trophic environment for these persistent and space-monopolizing taxa to establish high population densities.

Acknowledgements. This study was funded by the Cooperative Research Centre for the Great Barrier Reef World Heritage Area and the Australian Institute of Marine Science. We thank Glenn De'ath for extensive statistical advice. Kajsa Bergman, Jason Beringer, Udi Hauben, Jason How, Kate Rogulsky, Jo Stothard, James True, and Shaun Wilson were of great assistance in the field. Many thanks also to Jo Stothard and Udi Hauben who helped with the nutrient analyses. We greatly appreciate helpful comments on the manuscript by Ken Anthony, Jason Beringer, Glenn De'ath, Miles Furnas, Michele Skuza, and 2 anonymous reviewers.

\section{LITERATURE CITED}

Anthony KRN (1999) Coral suspension feeding on fine particulate matter. J Exp Mar Biol Ecol 232:85-106

Ayukai $T$ (1991) Standing stock of microzooplankton on coral reefs: a preliminary study. J Plankton Res 13:895-899
Ayukai T (1995) Retention of phytoplankton and planktonic microbes on coral reefs within the Great Barrier Reef, Australia. Coral Reefs 14:141-147

Barker Jørgensen C (1996) Bivalve filter feeding revisited. Mar Ecol Prog Ser 142:287-302

Bell PRF, Elmetri I (1995) Ecological indicators of large-scale eutrophication in the Great Barrier Reef lagoon. Ambio 24: $208-215$

Best B (1988) Passive suspension feeding in a sea pen: effects of ambient flow on volume flow rate and filtering efficiency. Biol Bull 175:332-342

Braun-Blanquet JJ (1964) Pflanzensoziologie, Grundzüge der Vegetationskunde, 3rd edn. Springer Press, Vienna

Campbell L, Nolla HA, Vaulot D (1994) The importance of Prochlorococcus to community structure in the Central North Pacific Ocean. Limnol Oceanogr 39:954-961

Cloern JE, Grenz C, Vidergar-Lucas L (1995) An empirical model of the phytoplankton:carbon ratio-the conversion factor between productivity and growth rate. Limnol Oceanogr 40:1313-1321

Coffroth MA (1984) Ingestion and incorporation of mucus aggregates by a gorgonian soft coral. Mar Ecol Prog Ser 17:193-199

Crossland CJ, Barnes DJ (1983) Dissolved nutrients and organic particulates in water flowing over coral reefs at Lizard island. Aust J Mar Freshw Res 34:835-844

Devantier LM, De'ath G, Done TJ, Turak E (1998) Ecological assessment of a complex natural system: a case study from the Great Barrier Reef. Ecol Appl 8:480-496

Dinesen ZD (1983) Patterns in the distribution of soft corals across the central Great Barrier Reef. Coral Reefs 1: $229-236$

Dommisse M, Furnas MJ (1998) Depositional fluxes and the macronutrient content of POM in the Great Barrier Reef: cross shelf and temporal variation. EOS, Transactions, Am Geophys Union 79:189

Done TJ (1982) Patterns in the distribution of coral communities across the central Great Barrier Reef. Coral Reefs 1: 95-107

Entsch BKG, Boto RG, Simand J, Wellington T (1983) Phosphorus and nitrogen in coral reef environments. Limnol Oceanogr 28:465-476

Erez J (1990) On the importance of food sources in coral-reef ecosystems. In: Dubinsky $Z$ (ed) Ecosystems of the World, Vol 25. Coral Reefs. Elsevier, Amsterdam

Fabricius KE (1997) Soft coral abundance in the central Great Barrier Reef: effects of Acanthaster planci and the physical environment. Coral Reefs 16:159-167

Fabricius KE (1998) Reef invasion by soft corals: which taxa and which habitats? In: Greenwood JG, Hall NJ (eds) Proceedings of the ACRS 75th Anniversary Conference, Heron Island, October 1997 School of Marine Science, The University of Queensland, Brisbane, p 77-90

Fabricius KE, De'ath G (1997) The effects of flow, depth and slope on cover of soft coral taxa and growth forms on Davies Reef, Great Barrier Reef. In: Lessios HA, Macintyre IG (eds) Proc 8th Int Coral Reet Symp, Balboa, Republic of Panama, p 1071-1076

Fabricius KE, Benayahu Y, Genin A. (1995a) Herbivory in asymbiotic soft corals. Science 268:90-92

Fabricius KE, Genin A, Benayahu Y (1995b) Flow-dependent herbivory and growth in zooxanthellae-free soft corals. Limnol Oceanogr 40:1290-1301 (Erratum: Limnol Oceanogr 41:1520)

Fabricius KE, Yahel G, Genin A (1998) In situ depletion of phytoplankton by an azooxanthellate soft coral. Limnol Oceanogr 43:354-356 
Furnas MJ (1991) Net in situ growth rates of phytoplankton in an oligotrophic, tropical shelf ecosystem. Limnol Oceanogr 36:13-29

Furnas MJ, Brodie J (1996) Current status of nutrient levels and other water quality parameters in the Great Barrier Reef. In: Hunter HM, Eyles AG, Rayment GE (eds) Downstream effects of land use. Department of Natural Resources, Queensland, p 9-21

Furnas MJ, Mitchell AW (1988) Photosynthetic characteristics of Coral Sea picoplankton $(<2 \mu \mathrm{m}$ size fraction $)$. Biol Oceanogr 5:163-182

Furnas MJ, Mitchell AW, Skuza M (1995) River inputs and sediment to the Great Barrier Reef. In: Wachenfeld D, Oliver J, Davis K (eds) State of the Great Barrier Reef World Heritage Area Workshop. Townsville 27-29 Nov 1995. Proceedings of the Great Barrier Reef Marine Park Authority, Townsville, Australia, p 46-68

Furnas MJ, Mitchel AW, Skuza M (1997) Shelf-scale nitrogen and phosphorus budgets for the central Great Barrier Reef. In: Lessios HA, Macintyre IG (eds) Proc 8th Int Coral Reef Symp. Smithsonian Tropical Research Institute, Balboa, p 809-814

Gili JM, Coma R (1998) Benthic suspension feeders: their paramount role in littoral marine food webs. Trends Ecol Evol 13:316-321

Glynn PW (1973) Ecology of a Caribbean reef. The porites reef-flat biotope: Part II. Plankton community with evidence for depletion. Mar Biol 22:1-21

Harbison GR, McAlister VL (1979) The filter-feeding rates and particle retention efficiencies of three species of Cyclosalpa (Tunicata, Thaliacea). Limnol Oceanogr 24:875-892

Johannes RE, Gerber R (1974) Import and export of net plankton by an Eniwetok coral reef community. Great Barrier Reef Committee, Brisbane 1:97-104

Larcombe P, Ridd PV, Prytz A, Wilson B (1995) Factors controlling suspended sediment on inner-shelf coral reefs, Townsville, Australia. Coral Reefs 14:163-171

Lasker HR, Gottfried MD, Coffroth MA (1983) Effects of depth on the feeding capabilities of two octocorals. Mar Biol 73 $73-78$

Lewis JB (1982) Feeding behaviour and feeding ecology of the Octocorallia (Coelenterata: Anthozoa). J Zool Lond 196:371-384

Marsh LM, Bradbury RH, Reichelt RE (1984) Determination of the physical parameters of coral distribution using line transect data. Coral Reefs 2:175-180

Editorial responsibility: Otto Kinne (Editor),

Oldendorf/Luhe, Germany
McCullagh P, Nelder JA (1989) Generalized linear models, 2nd edn. Chapman and Hall, London

Parsons TR, Maita Y, Lalli CM (1985) A manual of chemical and biological methods for sea water analysis. Pergamon Press, Oxford

Pile AJ (1997) Finding Reiswig's missing carbon: quantification of sponges feeding using dual-beam flow cytometry. Proc 8th Int Coral Reef Symp 2:1403-1410

Redfield AC, Ketchum BH, Richards FA (1963) The influence of organisms on the composition of seawater. In: Hill MN (ed) The sea, Vol 2. Wiley, New York, p 26-77

Revelante N, Gilmartin M (1982) Dynamics of phytoplankton in the Great Barrier Reef Lagoon. J Plankton Res 4 : $47-76$

Ribes M, Coma R, Gili JM (1998) Heterotrophic feeding by gorgonian corals with symbiotic zooxanthella. Limnol Oceanogr 43:1170-1179

Riisgård HU (1998) Filter feeding and plankton dynamics in a Danish fjord: a review of the importance of flow, mixing and density-driven circulation. J Environ Manag 53: $195-207$

Riisgărd HU, Poulsen L, Larsen PS (1996) Phytoplankton reduction in near-bottom water caused by filter-feeding Nereis diversicolor-implications for worm growth and population grazing impact. Mar Ecol Prog Ser 141:47-54

Sebens KP, Koehl MAR (1984) Predation on zooplankton by the benthic anthozoans Alcyonium siderium (Alcyonacea) and Metridium senile (Actiniaria) in the New England subtidal Mar Biol 81:255-271

Sorokin YI (1995) Coral reef ecology. Ecol Stud 102

Thorpe SA (1984) A laboratory study of stratified accelerating shear flow over a rough boundary. J Fluid Mech 138 $185-196$

Vogel S (1981) Life in moving fluids. The physical biology of flow. Princeton University Press, Princeton, NJ

Walker TA, O'Donnell G (1981) Observations of nitrate, phosphate and silicate in Cleveland Bay, northern Queensland Aust J Mar Freshw Res 32:877-887

Wolanski E (1987) Some evidence for boundary mixing near coral reefs. Limnol Oceanogr 32:735-739

Wolanski E, van Senden D (1983) Mixing of the Burdekin River Flood waters in the Great Barrier Reef. Aust J Mar Freshw Res 34:49-63

Yahel G, Post AF, Fabricius K, Marie D, Vaulot D, Genin A (1998) Phytoplankton distribution and grazing near coral reefs. Limnol Oceanogr 43:551-563

Submitted: June 2, 1999; Accepted: October 18, 1999

Proofs received from author(s): March 20, 2000 